\title{
' The Influence of Company Size, Fixed Asset Intensity, Leverage, Profitability, and Political Connection To Tax Avoidance
}

\author{
Aminah $^{1^{*}}$, Chairina ${ }^{2}$, and Yohana Yustika Sari ${ }^{3}$ \\ 1,2,3 Lambung Mangkurat University, Banjarmasin, Indonesia
}

\begin{abstract}
This study examines the influence of company size, fixed assets intensity, leverage, profitability and political connections against tax avoidance in manufacturing companies listed in the Indonesian Stock Exchange in the period of 2011-2015.

This study forms an associative research. The population used in this study are manufacturing companies listed in the Indonesian Stock Exchange. The sample used as many as 53 manufacturing companies listed in the Indonesian Stock Exchange in the period of 2011-2015 that are selected with the purposive sampling method, and so the number of sample data is 265 data. Tax Avoidance in this study was measured using the cash effective tax rate (CETR). Data can be analyzed by using the logistic regression.

The result showed that the profitability and political connections have influences to tax avoidance. While company size, intensity fixed assets and leverage do not influence tax avoidance.
\end{abstract}

Keywords: Company Size, Intensity Fixed Assets, Leverage, Profitability, Political Connections, Tax Avoidance

\section{INTRODUCTION}

Tax is an important instrument for the government in reaching economic, political, and social goals. Tax has a very important role in state life, specifically in implementing development, because tax is the most potential national income source and places the highest percentage in The Indonesian Budget compared with other income and funds all expenses including development expenses. Because of that, the government has a large concern in tax income, because the amount of income from tax has a large influence to the determined government budget (Dewinta \& Setiawan, 2016).

In reality tax income in Indonesia is not yet able to be reached maximally. Based on data from the dpr.go.id website and kemenkeu.go.id, the effectiveness of tax collection continuously experiences decrease from 2011-2015. Although always experiences decrease, tax collection effectiveness from 2011-2014 is still above $90 \%$, while in 2015 tax collection effectiveness is only as large as $83 \%$.

For maximizing tax income the government implements an effort by making and implementing tax regulation change. The government's effort for increasing tax income still has obstacles. One of the obstacles faced is the action of tax avoidance. According to Merks (2007) in Prakosa (2014) one of the means of

\footnotetext{
* Corresponding author. Email address: Aminah36mars@gmail.com
} 
implementing tax avoidance is implemented by moving the tax subject and/or the tax object to countries which provide specific tax treatment or tax relief (tax haven country) of an income type (substantive tax planning). Such as the recently globally stirred names which are involved in the scandal known as "The Panama Papers", that scandal also carries about 2,961 Indonesians which are famous and familiar in their home country. Panama Papers is a secret document which contains a list of big clients in the world, which are suspected to want their money to be hidden from tax whiff in their countries. In 11 million document pages, there are names of politicians, athletes, and celebrities which keep their money in companies abroad for tax avoidance (ekbis.sindonews.com).

Based on previous research tax avoidance is able to be influenced by several factors, among them are company size, fixed asset intensity, leverage, profitability, and political connection. Company size as a scale or value which is able to classify a company in the large or small category according to several ways such as total company assets, stock market value, average sales level and total sales (Cahyono, Andini \& Raharjo, 2016). The larger the company size, the more complex the implemented corporate transactions. This makes it possible for companies to take advantage of gaps or weaknesses present in the regulations of acts for implementing tax avoidance (Merslythalia \& Lasmana, 2016).

Asset intensity to companies illustrate the investment amount of companies to corporate fixed assets. The selection of investments in the form of fixed assets about tax is in the depreciation matter (Dharma \& Ardiana, 2016). The investment policy is assessed to be able to influence tax avoidance. Companies emphasize more on investing on fixed assets which will still pay lower tax because the depreciation burden increases, automatically income decreases so the paid tax is low (Maesarah, Atikah, \& Husnaini, 2015).

Leverage is another factor can influence companies to implement tax avoidance, according to Sudana (2011, p.20) leverage ratio measures the amount of debt use in corporate expense. Leverage appears because companies in their operations use assets and resources which causes fixed load for companies. Financial leverage appears because companies are provided with funds which cause fixed loads, which are debt, with interest as the fixed load. The larger the debt the company has the larger the interest load which appears. So a high interest load is able to provide influence of decreasing income as a cause of corporate tax.

Profitability ratio measures the ability of companies to produce profit by using resources that companies own, such as assets, capital, or corporate sales (Sudana, 2011, p.22). There are several ways for measuring profitability size, one of them which is the Return On Assets (ROA). ROA shows the ability of companies by using all owned assets for producing profit after tax. The higher the ROA value, the larger the profit companies obtain. When the obtained profit increases, the income tax total will increase according with the increase of corporate profit so there is a tendency for implementing tax avoidance which the company implements to increase (Dewinta \& Setiawan, 2016).

Companies are said to have political connections if at least one of the primary shareholders (persons who have at least $10 \%$ of options based on total stocks owned) or one of the directors (CEO, president director, vice president director, branch head or secretary) is a member of parliament, minister, or has a close relation with figures or political parties (Faccio, Masulis \& McConnell, 2006). Companies which have close relations with the government are defined as 
government owned companies in the form of state owned corporations. In other words, political connection is the level of intimacy of company relations with the government (Pranoto \& Widagdo, 2016). Companies which have political connections will make companies be more aggressive to implement tax planning (Butje \& Tjondro, 2014).

The research implemented by Dharma \& Ardiana (2016) who found that leverage has a negative influence to tax avoidance, fixed asset intensity has a negative influence to tax avoidance, company size has a positive influence to tax avoidance, and political connection does not influence tax avoidance.

The research implemented by Siregar \& Widyawati (2016) which found that profitability does not influence tax avoidance, leverage has an influence to tax avoidance, size has an influence to tax avoidance, capital intensity does not influence tax avoidance, and inventory intensity does not influence tax avoidance.

The research implemented by Dewinta \& Setiawan (2016) which found that company size has a positive influence to tax avoidance, profitability has a positive influence to tax avoidance, leverage does not influence tax avoidance and sales growth has a positive influence to tax avoidance.

Many results of previous research makes the researcher interested for retesting the factors which influence tax avoidance. The goal of this research is for knowing the influence of company size, fixed asset intensity, leverage, profitability and political connection to tax avoidance in manufacturing companies which are listed in the Indonesian Stock Exchange period 2011-2015.

\section{LITERATURE REVIEW AND HYPOTHESIS DEVELOPMENT}

\subsection{Agency Theory}

The agency theory leads to agency relations, owners (principals) which provide mandates to workers (agents). The agency theory explains about agency relations by using metamorphosis of a contract. The agency theory has a purpose for finishing: (1) agency problems which appear when there is a goal conflict between principals and agents and the difficulty of principals to implement agent work verification, (2) risk sharing problems which appear when principals and agents have different behaviors to risks (Ikhsan, Lesmana, \& Hayat, 2015, p.81).

The agency theory explains the presence of conflict which appears between owners and management of companies. This conflict is known as the agency problem (Jensen and Meckling, 1976 in Prakosa, 2014). The agency theory leads to the relation of owners (principals) which provide mandates to workers (agents). The behavior of tax avoidance can be influenced by the agency problem, one side of management wants compensation increase through high profit, the other party of shareholders want to suppress tax costs through low profit. So in the frame of bridging the agency problem the aggressive tax avoidance is used in optimizing both interests (Rusdi \& Martani, 2014).

\subsection{Tax Avoidance}

According to Suandy (2014, p.21), tax avoidance is the effort of decreasing legally what is implemented by taking advantage of regulation in the tax field optimally such as, exceptions and cuts which are allowed or using matters which are not yet arranged and present weaknesses in tax regulations which are applied.

According to Sumarsan (2013, p 8-9) tax avoidance occurs before the Tax Determination Letter is released. In this tax avoidance, taxpayers do not clearly 
violate acts even though sometimes it is clear that the interpretation of the act is not corresponding with the meaning and purpose of the creators of the act.

Tax avoidance is implemented with the means of:

\section{a. Refraining}

What is meant by refraining is that taxpayers do not implement anything which can be taxed.

b. Remote Location

Moving the business location or residence from a location that has high tax tariffs to a Location with low tax tariffs.

\subsection{Hypothesis}

\section{a. Influence of Company Size To Tax Avoidance}

Richardson and Lanis (2007) in Maesarah, Atikah \& Husnaini (2015) stated that the larger the company the lower the Cash Effective Tax Rate (CETR) that it has. This is because large companies are considered to be able to use the present resources for making tax planning which is good, and implementing activities in a way to be able to optimize tax savings. Tax planning which companies implement for the effort of suppressing tax as low as possible is able to be implemented by processing the total company assets for decreasing taxable income which is by taking advantage of the depreciation load and amortization which can be used as a subtraction of corporate taxable income.

In the research of Siregar \& Widyawati (2016), Maesarah, Atikah \& Husnaini (2015), Darmawan \& Sukartha (2014) stated that size has an influence to tax avoidance, while the research of Merslythalia \& Lasmana (2016) stated that company size does not influence tax avoidance. Because of that, it is expected that company size has an influence to tax avoidance, so the hypothesis is formulated as the following:

H1: Company size has an influence to tax avoidance.

\section{b. Influence of Asset Intensity to Tax Avoidance}

Fixed asset intensity to tax avoidance illustrates the corporate investment amount to corporate fixed assets. Investment policies are assessed to be able to influence tax evasion. Because of that managers will invest corporate idle funds for investing in fixed assets, with the purpose of obtaining profit in the form of depreciation which can cause corporate taxable profit to decrease and total paid tax will also decrease (Darmadi, 2013).

Ownership of fixed assets is able to decrease tax payments which companies pay for because the presence of a depreciation cost which is attached to fixed assets. Depreciation costs are able to be taken advantage by managers as agents for minimizing tax which companies pay for (Dharma \& Ardiana, 2016). Depreciation costs which are more and more higher will cause a decrease of total tax that companies pay for.

In the research of Dharma \& Ardiana (2016) it is stated that asset intensity still has a negative influence to tax avoidance, the research of Sutatik, Syafi'I \& Rahman (2015) stated that capital intensity has a positive influence to tax evasion, and while the research of Siregar \& Widyawati (2016) states that capital intensity does not influence to tax evasion. Because of that, it is expected that fixed assets still influence tax evasion so it is formulated as the following hypothesis: 
H2: Fixed asset intensity still influences to tax evasion.

\section{c. Influence of Leverage to Tax Avoidance}

Companies are able to use debt for fulfilling operational needs and corporate investment. But, debt will cause fixed costs known as interest costs. The larger the debt the taxable profit will be less because of tax incentives to debt interest (Prakosa, 2014). The addition of total tax will cause the presence of interest costs which the company pays. So the higher the value from leverage ratio, the higher the total funds from third party parties which the company uses and the higher also the interest costs which appear from the debt.

The high interest cost will provide an influence of a decrease in corporate tax load (Kurniasih \& Sari, 2013). The higher the corporate tax value the corporate Cash Effective Tax Rate (CETR) value will be lower (Richardson \& Lanis, 2007 in Dharma \& Ardiana, 2016). The lower the CETR value the higher chance the company will implement tax avoidance.

In the research of Dharma \& Ardiana (2016) it states that leverage has a negative influence to tax avoidance. Sutatik, Syafi'I \& Rahman (2015) stated that leverage has a positive influence to tax avoidance, and while the research of Dewinta \& Setiawan (2016) stated that leverage does not influence tax avoidance. Because of that, it is suspected that leverage has an influence to tax avoidance, so the following hypothesis is formulated:

H3: Leverage has an influence to tax avoidance.

\section{d. Influence of Profitability to Tax Avoidance}

Profitability consists of several ratios, one of them is the Return on Assets. Return on Assets (ROA) is an indicator which reflects corporate financial performance, the higher the ROA value which companies can reach the financial performance of the company is able to be categorized as well.

When obtained profit increases, the total income tax will increase corresponding with the corporate profit increase so the tendency to implement avoidance implemented by companies will increase for avoiding increase of total tax load to not decrease manager performance compensation (Dewinta \& Setiawan, 2016). Profitability has an influence to tax avoidance because companies are able to manage their assets well, one of the means is by taking advantage of the depreciation load and amortization and research and development loads which are able to be taken advantage as subtraction of taxable income (Darmawan \& Sukartha, 2014).

In the research of Siregar \& Widyawati (2016) stated that profitability does not influence to tax avoidance, while the research of Dewinta \& Setiawan (2016), Rinaldi \& Cheisviyanny (2015) stated that profitability has a positive influence to tax avoidance, Darmawan \& Sukartha (2014) stated that ROA has an influence to tax avoidance. Because of that it is suspected that profitability influences tax avoidance, so the hypothesis is as the following:

H4: Profitability has an influence to tax avoidance

e. Influence of Political Connection to Tax Avoidance 
The government as the owner of the company has an interest to the company for increasing corporate performance in the form of return investments of the company by the means of suppressing tax in debt, in one side the government also has a role in implementing national activities has an obligation to increase national income (Dharma \& Ardiana, 2016) So it causes its own conflict in the government, in one side the government as the owner has an interest in the company for increasing corporate performance and in the other side the government also has a role as the practitioner of national activities has an obligation to increase national income. The higher the government ownership, the higher the chance of the company to implement tax avoidance. (Dharma \& Ardiana, 2016).

In the research of Dharma \& Ardiana (2016) it states that political connection does not influence tax avoidance, while the research of Butje \& Tjondro (2016) states that political connection has a positive influence to tax avoidance, the research of Mulyani, Darminto \& Endang N.P (2014) stated that political connection has an influence to tax avoidance. Because of that, it is suspected that political connection has an influence to tax avoidance, so the following hypothesis is formulated:

H5: Political connection has an influence to tax avoidance

\section{RESEARCH METHOD}

\subsection{Population and Sample}

This research is an associative research, Associative research is the type of research which has a purpose for analyzing connections between one variable and other variables (Ulum \& Juanda, 2016, p. 78). The population in this research are all manufacturing companies which are listed in the Indonesian Stock Effect 20112015 period. The sample determining method in this research is implemented with purposive sampling. Total samples in this research are 265 samples. The sample selection process which it is based is observed in the following table 1: 
The Influence of Company Size, Fixed Asset Intensity, Leverage, Profitability, and Political

Connection To Tax Avoidance

Table 1 Sample Selection Process

\begin{tabular}{clc}
\hline No & \multicolumn{1}{c}{ Criteria } & Total \\
\hline 1 & $\begin{array}{l}\text { Total manufacturing companies listed in the Indonesian Stock Exchange } \\
\text { period 2011-2015 }\end{array}$ & 149 \\
\hline 2 & $\begin{array}{l}\text { Manufacturing companies which are not listed in a row for the research period } \\
\text { which is 2011-2015 }\end{array}$ & 22 \\
\hline 3 & $\begin{array}{l}\text { Manufacturing companies which are delisted for the research period which is } \\
\text { 2011-2015 }\end{array}$ & 5 \\
\hline 4 & $\begin{array}{l}\text { Companies which publish financial reports which do not end on December 31 } \\
\text { and not audited for the research period which is 2011-2015 }\end{array}$ & 4 \\
\hline 5 & Companies which experience loss for the research period which is 2011-2015 & 51 \\
\hline 6 & Companies which present financial reports other than rupiah (in dollars) & 11 \\
\hline 7 & $\begin{array}{l}\text { Manufacturing companies which do not provide complete data related with } \\
\text { tax avoidance for the research period which is 2011-2015. }\end{array}$ & 2 \\
\hline Companies which are selected as samples & 53 \\
\hline Total research years & 5 \\
\hline Jumlah seluruh sampel & 265 \\
\hline
\end{tabular}

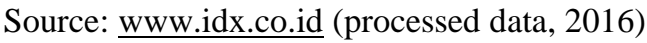

\subsection{Operational variable definition}

a. Dependent Variable

Tax avoidance is the effort of company action in taking advantage of opportunities which are present in tax acts, so they are able to pay lower taxes. For measuring tax avoidance in this research the Cash Effective Tax Rate (CETR) is used, which is the cash spent for tax costs divided with profit before tax (Budiman \& Setiyono, (2012).

The higher the CETR percentage which approaches the corporate income tax tariff as large as $25 \%$ it indicates that the tax avoidance level is lower (Dewinta $\&$ Setiawan, 2016). Because of that if the CETR count $<25 \%$ a value of 1 is given which indicates companies implement tax avoidance, while if the CETR value $>25 \%$ a value of 0 is given which indicates companies do not implement tax avoidance (Maesarah, Atikah, \& Husnaini, 2015) (Fikriyah, 2013).

b. Independent Variable

The independent variables in this research are company size, fixed asset intensity, leverage, profitability, and political connections.

\subsection{Data Analysis Technique}

The data analysis method which is used in this research is the logistic regression analysis. The regression model which will be formed in this research based on the logistic regression analysis is:

$$
\operatorname{Ln} \frac{p}{1-p}=\alpha_{0}+\beta_{1} \operatorname{SIZE}+\beta_{2} \mathrm{IAT}+\beta_{3} \mathrm{LEV}+\beta_{4} \mathrm{ROA}+\beta_{5} \mathrm{KP}+\mathrm{e}
$$

Remarks:

Ln $\frac{p}{1-p} \quad$ : Tax Avoidance Natural Log

$\alpha_{0} \quad$ : Constant 


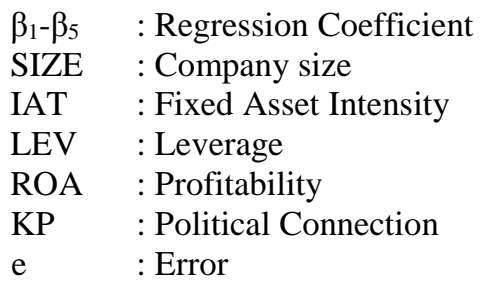

\section{RESULTS AND DISCUSSION}

\subsection{Hypothesis Test Results}

The overall model fit test shows -2log early like hood (Step 0) is as large as 351.261 After inputting five independent variables, the last -2log early like hood (Step 1) experienced decrease to become 328.527 . The $-2 \log$ early like hood experienced decrease as large as 22.734 . This decrease of -2log early like hood value shows that the hypothesized model fits with the data or as a whole the regression model used is a good model.

Based on the Hosmer and Lemeshow test the chi-square value is shown as 8.130 with a significance as large as 0.421 . Based on that matter, the significance value is larger than $0.05(0.421>0.05)$ so the model is concluded to be able to predict the observation value.

Determination coefficient test results provide information that the determination coefficient shown by Nagelkerke R square is 0.112 . This means the dependent variable variation which can be explained by independent variables is as large as $11.2 \%$, while the rest as large as $88.8 \%$ is explained by other variables outside the research model.

Hypothesis influence test results are in table 2 as the following:

Table 2 Hypothesis Test Results Summary

\begin{tabular}{lcc}
\hline \multicolumn{1}{c}{ Independent Variable } & Sig & Conclusion \\
\hline Company size (X1) & 0.615 & Does not Influence \\
\hline Fixed Asset Intensity (X2) & 0.480 & Does not Influence \\
\hline Leverage (X3) & 0.355 & Does not Influence \\
\hline Profitability (X4) & 0.001 & Influences \\
\hline Political Connections (X5) & 0.021 & Influences \\
\hline
\end{tabular}

Source: Data Processed from SPSS Output (2017)

a. Influence of Company Size to Tax Avoidance

The first hypothesis in this research stated that company size has an influence to tax avoidance. The hypothesis results test show that the company size variable has a positive coefficient as large as 0.041 with a significance level of 0.615 , which is larger than 0.05. Based on that result this research rejects H1, so it is concluded that company size does not influence tax avoidance.

Results of this research are in line with research results implemented by Merslythalia \& Lasmana (2016) and Prakosa (2014). Results of this research show that company size does influence the tax avoidance level because companies large and small are demanded to fulfill their tax obligations according with the applied 
regulations and managers as agents do not want to take risks with the presence of an inspection process or other sanctions which can cause negative impact for corporate image in the long term (Merslythalia \& Lasmana, 2016). So managers as agents are expected to not use their power for implementing tax evasion because there is a limit in the form of becoming the attention and target from regulator decisions (Watts and Zimmerman, 1986 in Prakosa, 2014).

\section{b. Influence of Fixed Asset Intensity to Tax Avoidance}

The second hypothesis in this research stated that fixed asset intensity has an influence to tax avoidance. The hypothesis results test show that the fixed asset intensity variable has a positive coefficient as large as 0.549 with a significance level of 0.480 , which is larger than 0.05 . Based on that result this research rejects $\mathrm{H} 2$, so it is concluded that fixed asset intensity does not influence tax avoidance.

Results of this research are in line with research results implemented by Siregar \& Widyawati (2016), Maesarah, Atikah and Husnaini (2015) and Mulyani Darminto \& Endang N.P (2014). This research shows that fixed asset intensity does not have an influence to tax avoidance. This is because company managers as agents make policies to fixed asset depreciation methods corresponding with the applied tax regulations, so companies do not need fiscal correction related with fixed asset depreciation in tax counting for the tax year (Haryadi, 2012 in Maesarah, Atikah and Husnaini 2015). Other than that the use of depreciation methods in sampling companies mostly use the straight line method.

As for depreciation methods which are allowed in tax regulations are only the straight line and declining balance (Mulyani, Darminto, \& Endang N.P, 2014), for the asset depreciation method in the form of structures are limited to just the straight line method, while tangible assets other than (not) structures uses the straight line method or decreasing balance (Suandy, 2016,p.36).

\section{c. Influence of Leverage to Tax Avoidance}

The third hypothesis in this research stated that leverage has an influence to tax avoidance. The hypothesis results test show that the leverage variable has a positive coefficient as large as 0.797 with a significance level of 0.533 , which is larger than 0.05 . Based on that result this research rejects H3, so it is concluded that leverage does not influence tax avoidance.

Results of this research are in line with research results implemented by Dewinta \& Setiawan (2016) and Maesarah, Atikah, and Husnaini (2015). Results of this research show that leverage does not influence tax avoidance, which means that the leverage value whether high or low does not influence the implementation of tax avoidance. Because in a company for covering deficiency of funding needs. The company has a choice of funds which are able to be used (Kasmir, 2015, p. 150) The source of funds meant are that companies choose more to use internal or external funds. Company managers as agents consider mote for choosing find sources, depending on the purpose, requirements, profit and ability of the company to use internal or external funds. Company managers as agents will consider more for choosing fund sources, depending on the purpose, requirements, profit, and ability of the company to fulfill the obligation (Kasmir, 2015, p.150). So company managers as agents implement funding sourced from loans or debt not only for implementing tax avoidance. Companies also already implement analysis about the 
possibility of risk of deciding to take debt which will be larger, compared with profit which the company will obtain from avoiding tax.

\section{d. Influence of Profitability to Tax Avoidance}

The fourth hypothesis in this research stated that profitability has an influence to tax avoidance. The hypothesis results test show that the profitability variable has a positive coefficient as large as 5.316 with a significance level of 0.001 , which is smaller than 0.05. Based on that result this research accepts $\mathrm{H} 4$, so it is concluded that profitability does influence tax avoidance.

Results of this research are in line with the research implemented by Dewinta \& Setiawan (2016), Rinaldi \& Cheisviyanny (2015) and Darmawan \& Sukhartha (2014). This research shows that profitability is able to influence tax avoidance. This shows that companies which have a high profitability tend to implement tax avoidance. A high profitability makes companies maximally capable in managing assets for obtaining profit. Managers as agents desire compensation increase through high profit, the other party the stockholders (principal) desire to suppress tax costs. Because of that, profit that the company obtains will be managed as good as possible by company managers (agents), among them is by implementing tax planning. The planning is implemented by maximizing loads which can become subtractions of taxable income such as amortization and research and development load.

\section{e. Influence of Political Connection to Tax Avoidance}

The fifth hypothesis in this research stated that political connection has an influence to tax avoidance. The hypothesis results test show that the political connection variable has a positive coefficient as large as 1.895 with a significance level of 0.021 , which is smaller than 0.05 . Based on that result this research accepts $\mathrm{H} 5$, so it is concluded that political connection does influence tax avoidance.

Results of this research are in line with research results implemented by Hardianti (2015), Mulyani, Darminto, \& Endang (2014) and Butje \& Tjondro (2016). This research shows that the presence of political connection which companies have influence tax avoidance. Companies which have political connections are proven to use it for tax evasion actions.

Companies are said to have political connections if at least one of the primary stockholders (persons who at least $10 \%$ of options based on total stocks they own) or one of the directors (CEO, president director, vice president director, branch head or secretary) is a member of parliament, minister, or have close relations with figures or political parties (Faccio, Masulis, \& McConnell, 2006). Companies which have close connections with the government are defined as government owned companies in the form of State Owned Enterprises. In other words, political connection is a level of intimacy of company relations with the government (Pranoto \& Widagdo). Political connections which companies have can be used by managers (agents) for obtaining capital aid and other advantages from funding, a low risk of tax examination makes companies aggressive in implementing tax planning which causes the decrease of financial report transparency (Butje \& Tjondro, 2014). 


\section{CONCLUSION AND SUGGESTIONS}

Results of this research show that the profitability variable and political connection has an influence to tax avoidance in manufacturing companies listed in the Indonesia Stock Exchange period 2011-2015. While the company size, asset intensity, and leverage do not influence to tax avoidance in manufacturing companies that are listed in the Indonesia Stock Exchange period 2011-2015.

This research has some limits which are expected to weaken research results. The limits in this research are: for measuring political connection it is only observed from one of the stockholders which are the government or State Owned Enterprises so it has not yet illustrates the political connection companies have as a whole.

For the government specifically the Directorate General of Tax, results of this research are expected to be an information consideration for implementing examination and a more in depth study about tax avoidance implemented by companies in Indonesia especially for those that have a high profitability and have political connections because in this research the profitability and political connection variables are proven to influence tax avoidance with the purpose of being cautious in examinations and making decisions and making policies in the future.

\section{References}

Akuntan Online. (30 Mei 2013). Ada 4000 PMA Mengaku Nilai Pajaknya Nihil. http://akuntanonline.com/showdetail.php? $\bmod =$ art\&id=505\&t=Ada4.000P MAMengaku20NilaiPajaknyaNihil\&kat=Perpajakan.

Arikunto, S. (2014). Prosedur Penelitian, Suatu Pendekatan Praktik. Jakarta: PT RINEKA CIPTA.

Brigham, E. F., \& Houston, J. F. (2014). Dasar-dasar Manajemen Keuangan (11 ed.). Jakarta: Salemba Empat.

Budiman, J., \& Setiyono. (2012). Pengaruh Karakter Eksekutif Terhadap Penghindaran Pajak (Tax Avoidance). Artikel Universitas Islam Agung, Universitas Gadjah Mada.

Butje, S., \& Tjondro, E. (2014). Pengaruh Karakter Eksekutif dan Koneksi Politik Terhadap Tax Avoidance. Tax dan Accounting Review, 4 (2), 1-9.

Cahyono, D. D., Andini, R., \& Raharjo, K. (2016). Pengaruh Komite Audit, Kepemilikan Institusional, Dewan Komisaris, Ukuran Perusahaan (Size), Leverage (DER), dan Profitabilitas (ROA) Terhadap Tindakan Penghindaran Pajak (Tax Avoidance) Pada Perusahaan Perbankan Yang Listing BEI Periode Tahun 2011-2013. Journal Of Accounting, 2 (2).

Darmadi, I. N. (2013). Analisis Faktor Yang Mempengaruhi Manajemen Pajak Dengan Indikator Tarif Pajak Efektif. [Skripsi]. Semarang: Fakultas Ekonimi dan Bisnis Universitas Diponegoro. 
Darmawan, I. H., \& Sukartha, I. M. (2014). Pengaruh Penerapan Corporate Governance, Leverage, Return On Assets, dan Ukuran Perusahaan Pada Penghindaran Pajak. E-Jurnal Akuntansi Universitas Udayana, 143-161.

Dewinta, I. A., \& Setiawan, P. E. (2016). DewinPengaruh Ukuran Perushaan, Umur Perusahaan, Profitabilitas, Leverage dan Pertumbuhan Penjualan Terhadap Tax Avoidance. E- Jurnal Akuntansi Universitas Udayana, 14 (3), ISSN: 2302-8556.

Dharma, I. S., \& Ardiana, P. A. (2016). Pengaruh Leverage, Intensitas Aset Tetap, Ukuran Perusahaan dan Koneksi Politik Terhadap Tax Avoidance. E-Jurnal Akuntansi Universitas Udayana, 15, 584-613, ISSN:2302-8556.

Faccio, M. (2006). Politically Connected Firms. The American Economic Review, 96 (1), 369-386.

, M., Masulis, R. W., \& McConnell, J. J. (2006). Political Connections and Corporate Bailouts. The Journal Of Finance, LXI (6), 2597-2635.

Fajriah, L. R. (05 April 2016). Tanggapan Apindo Soal 2.961 Orang RI Masuk List Panama Papers.http://ekbis.sindonews.com/read/1098439/33/tanggapanapindo-soal-2-961-orang-ri-masuk-list-panama-papers-1459843814.

Fikriyah. (2013). Analisis Pengaruh Likuiditas, Leverage, Profitabilitas dan Karakteristik Kepemilikan Terhadap Agresivitas Pajak Perusahaan. Jurusan Manajemen Fakultas Ekonomi UIN Maliki Malang.

Ghozali, I. (2016). Aplikasi Analisis Multivariete Dengan Program IBM SPSS 23 Edisi 8. Semarang: Badan Penerbit Universitas Diponegoro.

Halim, A., Bawono, I. R., \& Dara, A. (2014). Perpajakan: Konsep, Aplikasi, Contoh, dan Studi Kasus. Jakarta: Penerbit Salemba Empat.

Hanafi, M. M. (2015). Manajemen Keuangan. Yogyakarta: BPFE-Yogyakarta.

Hardianti, E. P. (2015). Analisis Tindakan Penghindaran Pajak Pada Perusahaan Yang Mempunyai Koneksi Politik. 1-25.

Hartono, J. (2016). Teori Portofolio dan Analisis Investasi Edisi Kesepuluh. Yogyakarta: BPFE-Yogyakarta.

Heryuliani, N. (2015). Pengaruh Karakteristik Perusahaan dan Kepemilikan Keluarga Terhadap Penghindaran Pajak. [Skripsi]. Universitas Islam Negeri Syarif Hidayatullah Jakarta.

Hilmi, U., \& Ali, S. (2008). Analisis Faktor-Faktor Yang Mempengaruhi Ketepatan Waktu Penyampaian Laporan Keuangan (Studi Empiris Pada PerusahaanPerusahaan yang Terdaftar di BEJ Periode 2004-2006). Simposium Nasional Akuntansi XI Ikatan Akuntansi Indonesia. 
The Influence of Company Size, Fixed Asset Intensity, Leverage, Profitability, and Political

Connection To Tax Avoidance

IAI. (2011). PSAK 16 (Revisi 2011) Pernyataan Standar Akuntansi Keuangan Aset Tetap.

Ikhsan, A., Lesmana, S., \& Hayat, A. (2015). Teori Akuntansi. Bandung: Citapustaka Media.

A., Muhyarsyah, Tanjung, H., \& Oktaviani, A. (2014). Metodologi Penelitian Bisnis. Bandung: Citapustaka Media.

Kasmir. (2015). Analisis Laporan Keuangan. Jakarta: PT Raja Grafindo Persada.

Kurniasih, T., \& Sari, M. M. (2013). Pengaruh ROA, Leverage, Corporate Governance, Ukuran Perusahaan dan Kompensasi Rugi Fiskal Terhadap Tax Avoidance. Buletin Studi Ekonomi, 18 (1), 58-66.

Maesarah, Y., Atikah, S., \& Husnaini, W. (2015). Pengaruh Karakteristik Perusahaan dan Corporate Social Responbility Terhadap Penghindaran Pajak. Konferensi Regional Akuntansi (KRA) II Jawa Timur.

Mardiasmo. (2011). Perpajakan Edisi Revisi. Yogyakarta: ANDI.

Merslythalia, D. R., \& Lasmana, M. S. (2016). Pengaruh Kompetensi Eksekutif, Ukuran Perusahaan, Komisaris Independen dan Kepemilikan Institusional Terhadap Tax Avoidance (Studi Empiris Perusahaan Manufaktur Terdaftar di BEI Tahun 2012-2014). Jurnal Ilmiah Akuntansi dan Bisnis, 11(2), 116123.

Mulyani, S., Darminto, \& Endang N.P, M. W. (2014). Pengaruh Karakteristik Perusahaan, Koneksi Politik dan Reformasi Perpajakan Terhadap Penghindaran Pajak (Studi Pada Perusahaan Manufaktur Yang Terdaftar di BEI tahun 2008-2012). Jurnal Mahasiswa Universitas Brawijaya, 1 (2), 1-9.

Muzakki, R. M. (2015). Pengaruh Corporate Social Responsibility dan Capital Intensity Terhadap Penghindaran Pajak. [Skripsi]. Semarang: Fakultas Ekonomika dan Bisnis Universitas Diponegoro.

Peraturan Menteri Keuangan. (2009). Peraturan Menteri Keuangan Republik Indonesia Nomor 96/PMK.03/2009 Tentang Jenis-Jenis Harta Yang Termasuk Dalam Kelompok Harta Berwujud Bukan Bangunan Untuk Keperluan Penyusutan. Jakarta.

Prakosa, K. B. (2014). Pengaruh Profitabilitas, Kepemilikan Keluarga dan Corporate Governance Terhadap Penghindaran Pajak Di Indonesia. SNA 17 Mataram, Lombok Universitas Mataram 24-27 September.

Pranoto, B. A., \& Widagdo, A. K. (n.d.). Pengaruh Koneksi Politik dan Corporate Governance terhadap Tax Aggressiveness. Syariah Paper Accounting FEB UMS ISSN 2460-0784. 
Pudjiastuti, Husnan, S., \& Enny. (2015). Dasar-dasar Manajemen Keuangan. Yogyakarta: UPP STIM YKPN.

Rinaldi, \& Cheisviyanny, C. (2015). Pengaruh Profitabilitas, Ukuran Perusahaan dan Kompensasi Rugi Fiskal Terhadap Penghindaran Pajak. Seminar Nasional Ekonomi Manajemen dan Akuntansi Fakultas Ekonomi Universitas Negeri Padang, 472-483.

Rusydi, M. K., \& Martani, D. (2014). Pengaruh Struktur Kepemilikan Terhadap Aggressive Tax Avoidance. Simposium Nasional Akuntansi (SNA) XVII.

Siregar, R., \& Widyawati, D. (2016). Pengaruh Karakteristik Perusahaan Terhadap Penghindaran Pajak Pada Perusahaan Manufaktur Di BEI. Jurnal Ilmu dan Riset Akuntansi, 5 (2), ISSN: 2460-0585.

Suandy, E. (2014). Hukum Pajak Edisi 6. Jakarta: Salemba Empat.

E. (2016). Perencanaan Pajak Edisi 6. Jakarta: Salemba Empat.

Sudana, I. M. (2011). Manajemen Keuangan Perusahaan Teori dan Praktik. Jakarta: Penerbit Erlangga.

Sugiyono. (2014). Metodologi Penelitian Bisnis. Bandung: Alfabeta.

Sumarsan, T. (2013). Perpajakan Indonesia Edisi 3 Pedoman Perpajakan yang Lengkap Berdasarkan Undang-Undang Terbaru. Jakarta: Indeks.

Sutatik, Syafi'i, \& Rahman, A. (2015). Analisis Pengaruh Karakteristik Perusahaan dan Biaya Bunga Terhadap Penghindaran Pajak. Jurnal Akuntansi UBHARA, 1 (3), 261-270.

Ulum, I., \& Juanda, A. (2016). Metodologi Penelitian Akuntansi (2 ed.). Malang: Aditya Media Publishing.

Undang-Undang No. 36 Tahun 2008 Perubahan Keempat atas Undang-Undang No. 7 Tahun 1983 Tentang Pajak Penghasilan. (t.thn.).

Van Horne, J. C., \& Wachowicz, J. J. (2014). Prinsip-prinsip Manajemen Keuangan Edisi 13 Buku 1. Jakarta: Salemba Empat.

www.dpr.go.id accessed on Desember 312016

www.idx.co.id accessed on Oktober 42016

www.kemenkeu.go.ig accessed on Desember 312016

www.lampost.co accessed on Januari 282017

www.merdeka.com accessed on Januari 282017

www.ortax.org accessed on Oktober 92016

www.sahamok.com accessed on September 172016 